\title{
PENDAMPINGAN BELAJAR MEMBENTUK KARAKTER ANAK YANG TERDAMPAK PANDEMI COVID-19 MELALUI KEGIATAN INTERAKSI ALAM DAN SOSIAL DI DUSUN KRAJAN DESA KEDUNGGEBANG KECAMATAN TEGALIMO KABUPATEN BANYUWANGI
}

\author{
Ansari $^{1)}$, Siti Maulida Ulva ${ }^{2)}$, \\ Institut Agama Islam (IAI) Ibrahimy Genteng Banyuwangi, Indonesia \\ e-mail : ansaridosen1@gmail.com
}

\begin{abstract}
Aqidah Ahlus Sunnah Wal Jama'ah (Aswaja) is the largest aqidah followed by Muslims all over the world. This Aqidah Aswaja contains elements of Islamic aqidah that are relevant and accepted by both naqli and aqli arguments. Moreover, Aswaja's aqidah principles are in accordance with the teachings of Islam which is Rahmatal lil 'Alamiin, which is tawasut or moderate in nature, not extreme right or extreme left.
\end{abstract}

KEYWORDS: Learning Mentoring, Natural Interaction, Social

\begin{tabular}{|c|c|c|}
\hline Accepted: & Reviewed: & Published: \\
January 05 2021 & January 14 2021 & February 15 2021 \\
\hline
\end{tabular}

\section{PENDAHULUAN}

Pendidikan merupakan hal yang sangat penting bagi kehidupan manusia, karena pendidikan merupakan sektor yang mendukung dalam meningkatkan dan mengembangkan sumber daya manusia (human resources development) untuk menjawab tantangan masa depan yang berat akibat makin berkembangnya ilmu pengetahuan dan teknologi, terutama dalam pemanfaatannya. Kualitas sumber daya manusia yang dihasilkan dari institusi pendidikan, yaitu sekolah, maka dari itu sekolah merupakan salah satu tolak ukur dan modal dalam membangun karakter anak bangsa dan negara menjadi lebih baik lagi. Adapun salah satu dalam membangun karakter anak bangsa yakni dengan kegiatan interaksi sosial dan alam, hal ini merupakan sebuah proses terbentuknya karakter seseorang yang mana dengan berbagai cara berhubungan, seperti kegiatan pramuka, bazar antar kelas dan kegiatan ektrakurikuler lainnya.

Menurut Morin (As' adi \& Muttaqin, 2019) Pendidikan merupakan 
bagian terpenting dari masyarakat. Pendidikan adalah wadah manusia untuk mengembangkan ilmu pengetahuan dan teknologi serta berbagai aspek lainnya. Pendidikan di era globalisasi juga memberikan dampak yang signifikan bagi pengembangan pola pikir masyarakat di dalam membaca situasi dan kondisi yang terjadi di suatu negara. Pendidikan merupakan dasar terjadi suatu perubahan. Melalui pendidikan, masyarakat dapat mengetahui cara yang tepat untuk menyesuaikan cara berpikir untuk menghadapi tantangan dunia yang semakin kompleks dan membutuhkan daya saing yang tinggi.

Pendidikan karakter diharapkan mampu sebagai solusi dan sebagai transformasi yang baik dalam menumbuhkan karakter positif serta membentuk akhlak mulia anak agar menjadi lebih baik. bahkan upaya-upaya yang dilakukan oleh pemerintah untuk mengatasi maslahmasalah tersebut salah satunya, menerapkan pendidikan karakter di sekolah-sekolah. Hal ini sudah mejadi aturan dalam UU Nomor 29 Tahun 2003 tentang Sistem Pendidikan Nasional menegaskan yaitu:

"Pendidikan Nasional berfungsi mengembangkan kemampuan dan membentuk watak serta peradaban bangsa yang bermartabat dalam rangka mencerdaskan kehidupan bangsa, bertujuan untuk berkembangnya potensi peserta didik agar menjadi manusia yang beriman dan bertakwa kepada Tuhan Yang Maha Esa, berakhlak mulia, sehat, berilmu, cakap, kreatif, mandiri dan menjadi warga negara yang demokratis serta bertanggung jawab".

Seperti firman Allah SWT:

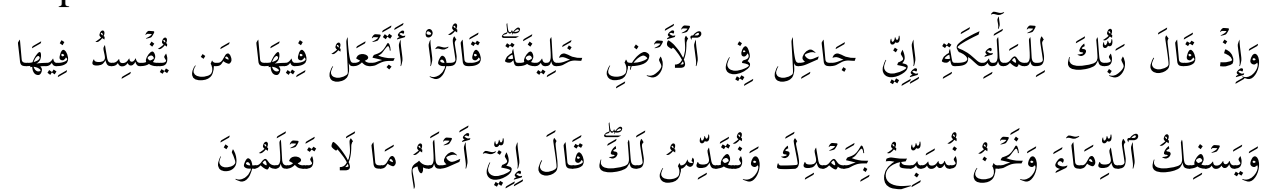

"Ingatlah ketika Tuhanmu berfirman kepada Para Malaikat: "Sesungguhnya aku hendak menjadikan seorang khalifah di muka bumi." mereka berkata: "Mengapa Engkau hendak menjadikan (khalifah) di bumi itu orang yang akan membuat kerusakan padanya dan menumpahkan darah, Padahal Kami Senantiasa bertasbih dengan memuji Engkau dan mensucikan Engkau?" Tuhan berfirman: "Sesungguhnya aku mengetahui apa yang tidak kamu ketahui." (Q.S. AlBaqarah 2: 30).

Dari ayat ditersebut dapat di simpulkan bahwa manusia dijadikan oleh Allah SWT sebagai kholifah di muka bumi ini, yaitu diberi wewenang oleh Allah agar melaksanakan perintahnya di muka bumi untuk mengelola bumi dan 
77 | Pendampingan Belajar Membentuk Karakter Anak Yang Terdampak Pandemi Covid-19 Melalui Kegiatan Interaksi Alam Dan Sosial Di Dusun Krajan Desa Kedunggebang Kecamatan Tegaldlimo Kabupaten Banyuwangi

seisinya, serta kemampuan untuk menghindari pertumpahan darah dan kerusakan.

Selain itu juga dalam firman Allah surat Al-Baqarah 60 yaitu:

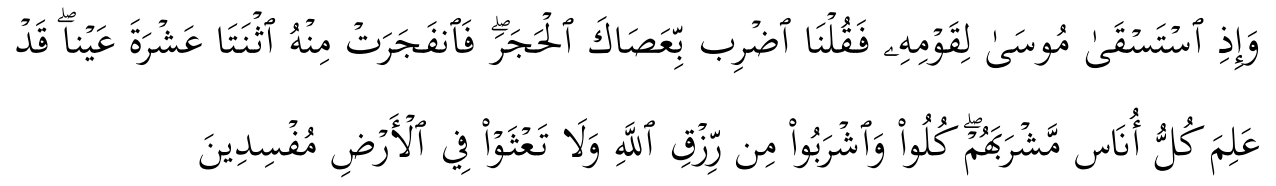

"Dan (ingatlah) ketika Musa memohon air untuk kaumnya, lalu Kami berfirman: "Pukullah batu itu dengan tongkatmu". lalu memancarlah daripadanya dua belas mata air. sungguh tiap-tiap suku telah mengetahui tempat minumnya (masing-masing). Makan dan minumlah rezki (yang diberikan) Allah, dan janganlah kamu berkeliaran di muka bumi dengan berbuat kerusakan." (Q.S. Al-Baqarah 2: 60).

Dari ayat di atas sudah jelas bahwa tanggung jawab manusia sebagai khalifah di muka bumi ini yaitu untuk menjaga bumi dari kerusaan di berbagai belahan bumi, sehingga suatu kegiatan yang hubungan interaksi sosial dengan adanya lembaga sosial adalah terbentuknya perilaku manusia yang sesuai dengan norma atau nilai yang berlaku dalam masyarakat. Karena adanya pendidikan membantu manusia menjadi sadar terhadap peran dan tanggung jawab sehingga senantiasa meningkatkan potensi diri untuk menghadapi tantangan dan perubahan kehidupan kedepannya. Dalam hal ini seperti yang tertulis dalam Undang-Undang No. 20 Tahun 2003 Sistem Pendidikan Nasional Pasal 1 ayat 1 bahwa Pendidikan merupakan usaha sadar dan terencana untuk mewujudkan suasana belajar dan proses pembelajaran agar peserta didik secara aktif mengembangkan potensi dirinya untuk memiliki kekuatan spiritual keagamaan, pengendalian diri, kepribadian, kecerdasan, akhlak mulia serta keterampilan yang di perlukan dirinya, masyarakat, bangsa, dan negara.

Akan tetapi setelah adanya virus covid-19 yang menyebar di seluruh dunia menjadikan suatu hal penutupan sementara lembaga pendidikan sebagai upaya menahan penyebaran pendemi covid-19 yang berdampak pada jutaan pelajar, tidak kecuali di Indonesia. Hal ini penjadikan suatu beban dan merupakan tanggung jawab semua elemen pendidikan khususnya negara dalam memfasilitasi kelangsungan sekolah bagi semua steakholders pendidikan guna melakukan pembelajaran jarak jauh, dan anjuran dari WHO (World Health Organization) pendidikan harus menerapkan belajar dengan sistem WFH (work 
from home) yaitu belajar dari rumah bukan WFO (work from office) yaitu belajar disekolahan. Sebagaimana mestinya Indonesia merencanakan, mempersiapkan, dan mengatasi pemulihan covid-19, untuk menekan kerugian dunia pendidikan dimasa mendatang.

Adapun Coronavirus adalah penyakit, zoonosis (ditularkan antara hewan dan manusia). Kasus ini diawali dengan informasi dari (WHO), tanggal 31 Desember 2019 yang menyebutkan adanya kasus pneumonia yang tidak jelas di Kota Wuhan, Provinsi Hubei, China. Kasus ini terus berkembang, Pada tanggal 30 Januari 2020, WHO menetapkan COVID-19 sebagai Public Health Emergency of International Concern (PHEIC) Kedaruratan Kesehatan Masyarakat Yang Meresahkan Dunia (KKMMD). Tanggal 12 Februari 2020, WHO resmi menetapkan penyakit novel coronavirus pada manusia ini dengan sebutan Coronavirus Disease (COVID19). Tanggal 2 Maret 2020 Indonesia telah melaporkan 2 kasus.Tanggal 11 Maret 2020, WHO sudah menetapkan COVID19 sebagai pandemi. (Yurianto A., 2020). Untuk itu dunia pendidikan khususnya dunia pembelajaran selalu membutuhkan inovasi belajar apalagi di era pandemi covid-19 saat ini, terutama bagi orang tua yang memiliki putra-putri di jenjang TK/SD yang sangat membutuhkan inovasi pembelajaran, terutama dalam pembentukan karakter anak.

Menurut Schumpeter (2010) inovasi artinya mengusahakan melakukan kreasi dan implementasi sesuatu yang baru dengan berbagai kombinasi, sehingga tercipta atau menghasilkan hal bermanfaat dan menguntungkan. Sementara pengertian pembelajaran adalah sebuah proses yang menitikberatkan pada pendidikan, pelatihan, pembentukan dan pengembangan potensi seseorang dari proses belajar mengajar. Dari penjelasan diatas dapat di simpulkan bahwa inovasi pembelajaran adalah upaya yang dilakukan oleh individu atau kelompok dari kreasi pengajaran yang bersifat baru, memberikan manfaat, menguntungkan dengan menggunakan potensi seseorang melalui proses belajar dan mengajar.

Ada beberapa teori yang digunakan tentang inovasi pembelajaran menurut ahli yaitu, teori adopsi dari Roger (2012) bahwa inovasi merupakan suatu ide, gagasan, kreasi dan temuan baru yang bermanfaat dan menguntungkan. Robbins (2010) mengemukakan teori inspirasi bahwa inovasi adalah hasil dari aspirasi berbagai gagasan baru yang diterapkan untuk menginspirasikan dan memprakarsai terjadinya perbaikan. Van De Ven (2013) dengan teori interpretasi bahwa inovasi adalah interpretasi dari gagasan konstruktif dan brilliant secara bermanfaat. Acuan teori ini menjadikan inovasi pembelajaran sebagai sebuah komponen penting yang diperlukan dalam 
79 | Pendampingan Belajar Membentuk Karakter Anak Yang Terdampak Pandemi Covid-19 Melalui Kegiatan Interaksi Alam Dan Sosial Di Dusun Krajan Desa Kedunggebang Kecamatan Tegaldlimo Kabupaten Banyuwangi

mewujudkan pembelajaran yang efektif sesuai:

1. Kebutuhan pembelajaran;

2. Integrasi pembelajaran;

3. Aplikasi pembelajaran;

4. Aktivasi pembelajaran;

5. Demonstrasi pembelajaran.

Kelima komponen ini menjadi penting sebagai inovasi pembelajaran yang berkaitan dengan konsep manajemen sekolah dan tata kelola yang berkaitan dengan kegiatan sekolah dalam hal membentuk karakter siswa dan pengenalan jiwa sosial kemasyaratan di era covid-19 saat ini.

Sesuai dengan observasi yang dilakukan peneliti, bahwa ada beberapa permasalahan diantarnya:

1. Banyak orang tua anak yang terdampak covid-19 di Desa Kedunggebang yang terletak di Kecamatan Tegaldlimo Kabupaten Banyuwangi yang mengeluh mengenai bagaimana inovasi membentuk karkter putra putrinya.

2. Ada Sebagian anak yang terdampak pandemi, tidak mau peduli terhadap pekerjaan orang tua maupun orang lain dan kurangnya pengetahuian bagaimana pentinya sosialisasi terhadap orang lain atau lingkungan sekitarnya.

Hal ini dikarenakan anak lebih banyak bermain gadget di masa libur sekolah di era pandemi Covid-19 saat ini, hal ini mengakibatkan kesulitan anak dalam membangun hidup bersosialisasi dengan lingkungan. Adapun menurut pandangan ibu Nik (2020) salah satu dari orang tua anak yang terdampak pandemi covid ujar beliau, bahwa banyak sekali kerugian yang menjadikan orang tua tidak bisa mengontrol kegiatan bermain gadget putra putrinya yaitu seperti: kurangnya bersosialisasi terhadap lingkungan dikarenakan dia asik dengan bermain gadgetnya yang menyebabkan anak sering mengurungkan diri di rumah, kurang kontak langsung dengan teman-teman sebayanya atau orang lain sehingga anak memilikiki karakter yang tidak baik, bahkan banyak anak yang melawan orang tua karena lebih mementingkan bermainnya. Selain itu juga, melansir Very Well Family (2020) mengemukakan bahwa, kecanduan gadget bisa membuat anak mengalami penularan akademik. Melihat persoalan tersebut menjadikan ketidak inginan harapan orang tua dalam membentuk karakter anakanaknya, terutama di era pandemi covid-19 saat ini, yakni anjuran dari WHO (World Health Organization) bahwa pendidikan harus menerapkan belajar dengan sistem WFH (work from home) yaitu belajar dari rumah bukan WFO (work from office) yaitu belajar disekolahan, sehingga mereka kebingungan 
dalam membentuk dan mendampingi pembelajaran karakter pada putra-putrinya karena kurangnya inovasi pembelajaran yang dimiliki. Sehingga peneliti mengarahkan melalui kegiatan interaksi alam dan sosial di area sekitar akan membangkitkan semangat belajar anak dan mengarahkan kebiasaan anak dalam membentuk karakter yang baik serta membantu orang tua dalam hal metode pengajaran inovasi untuk membentuk karakter anak-anaknya dan pembelajaran relige terutama disaat libur sekolah di era pandemi covid-19 ini dengan ketentuan harus tetap mengikuti protokol kesehatan.

\section{METODE PELAKSANAAN}

Metode pelaksanaan kegiatan ini sebagai berikut:

\section{Tahap Persiapan}

a. Survei atau observasi lokasi penelitian untuk memperkuat kegiatan rill yang perlu dilakukan untuk melangkah penelitian kedepan

b. Program dapat dimonitoring dengan cara datang langsung ketempat anak yang terdampak covid-19 dengan melakukan pendekatan terhadap anak dan pihak keluarga untuk menentukan solusi yang ditawarkan dalam suatu permasalahan.

c. Menyusun pelaksanaan penelitian dengan menjalin kerjasama dan berkomunikasi dengan pihak keluarga anak, guru dan bapak RT, untuk kelancaran pelaksanaan kegiatan.

\section{Tahap Pelatihan dan Pendampingan}

a. Sosialisasi

Pelaksanaan kegiatan diawali pendekatan dengan anak yang terdampak pandemi covid-19 di desa Kedunggebang dan Menjalin kerjasama dan berkomunikasi dengan pihak keluarga anak, guru dan bapak RT untuk mensinergikan kegiatan-kegiatan yang akan dilakukan berkaitan dengan pembentukan karakter anak yang sesuai dengan keinginan orang tua. Kegiatan ini di arahkan untuk menyadarkan pentingnya kita dalam hal bersosialisasi terhadap lingkungan sekitar dengan menggunakan inovasi pembelajaran interaksi alam dan sosial di masa hari libur sekolah dengan tetap menggunakan protokol kesehatan.

b. Pelatihan dan Pendampingan

1) Pelatihan, dilakukan terkait dengan pembentukan suatu karakter yang baik yang di inginkan oleh orang tua. Dalam hal ini akan dilakukan suatu pembelajaran dengan melalui kegiatan interaksi alam dan sosial 
81 | Pendampingan Belajar Membentuk Karakter Anak Yang Terdampak Pandemi Covid-19 Melalui Kegiatan Interaksi Alam Dan Sosial Di Dusun Krajan Desa Kedunggebang Kecamatan Tegaldlimo Kabupaten Banyuwangi

di lingkungan sekitar rumah mereka dengan tetap menggunakan protokol kesehatan.

2) Pendampingan belajar, dilaksanakan dalam bentuk pendampingan aktifitas sehari-hari di rumah, mulai dari pengenalan taman di rumah, perawatan kolam ikan di rumah, bahkan suatu kegiatan juga di arahkan di sebuah perkebunan ataupun di persawahan sekitar rumah mereka. Selain itu suatu kegiatan juga di arahkan dalam bentuk sosialisasi dengan masyarakat terdekat lingkungan mereka dengan tetap mengikuti protokol kesehatan, sehingga suatu kegiatan tersebut merubah pola fikir mereka menjadi anak yang peduli terhadap lingkungan sekitar mereka. Selain kegiatan diatas suatu pendekatan juga dilakukan melalui kagiatan relegi dalam artian melalui kegiatan mengaji yangmana merubah menset mereka untuk peduli pada dirimereka untuk selalu dekat dengan Allah SWT.

c. Tahap Evaluasi

Dilakukan untuk melihat tingkah keberhasilan kagiatan mulai dari awal, proses, hingga pencapaian hasil kegiatan.

Kegiatan pengabdian ini dilakukan sejak adanya surat ijin penelitian, yaitu pada bulan Juni 2020 s/d Juli 2020. Penelitian ini berlokasi di desa Kedunggebang, Kecamatan Tegaldlimo, Kabupaten Banyuwangi. Kehadiran peneliti dilapangan ini bersifat terang-terangan, terbuka, dan status peneliti diketahui oleh informan. Adapun peneliti dalam pengumpulan data menemui secara langsung pihak-pihak yang terdampak dan informan mengenai pembelajaran melalui kegiatan interaksi alam dan sosial untuk membentuk kepribadian yang baik melalui proses wawancara, observasi dan dokumentasi. Kegiatan pendampingan ini di terapkan oleh peneliti sebanyak 5 anak.

\section{HASIL DAN PEMBAHASAN}

\section{Pendampingan Belajar Membentuk Karakter Anak Yang Terdampak Pandemi Covid-19 Dengan Melalui Kegiatan Interaksi Alam Dan Sosial di Dusun Krajan}

Menurut Muslich (2011) mengatakan bahwa pendidikan karakter merupakan suatu sistem penanaman nilai-nilai karakter kepada warga sekolah yang meliputi komponen pengetahuan, kesadaran, atau kemauan, dan tindakan untuk melaksanakan nilai-nilai tersebut baik terhadap Tuhan Yang Maha Esa, diri sendiri, sesama, lingkungan, maupun kebangsaan sehingga 
menjadi manusia insan kamil.

Menurut Ki Hadjar Dewantara, karakter atau kata yang digunakan adalah budi pekerti yang merupakan kebulatan jiwa manusia yang mewujud dalam kesatuan gerak pikiran, perasaan dan kehendak atau kemauan yang kemudian menghasilkan tenaga untuk senantiasa memikirmikirkan, merasarasakan serta selalu memakai ukuran, timbangan dan dasar-dasar yang pasti dan tetap. Peran penting karakter dalam kehidupan dan untuk menghasilkan sumber daya manusia (peserta didik) yang unggul di segala aspek, maka karakter mulai menjadi perhatian serius dalam dunia pendidikan. Perkembangan ini melahirkan konsep pendidikan karakter yang diterapkan di berbagai kehidupan terutama di lembaga pendidikan. Bahkan Ki Hadjar Dewantara telah merumuskan karakter dalam pengertian pendidikan yaitu daya upaya untuk memajukan bertumbuhnya budi pekerti (kekuatan batin, karakter), pikiran (intellect) dan tubuh anak sehingga dapat memajukan kesempurnaan hidup yang selaras dengan dunia yang terus berubah. Karakter diartikan sebagai pendidikan budi pekerti yang harus menggunakan syaratsyarat yang selaras dengan jiwa kebangsaan menuju kepada kesucian, ketertiban, dan kedamaian lahir batin, tidak saja syarat-syarat yang sudah ada dan ternyata baik, melainkan juga syarat- syarat jaman baru yang bermanfaat dan sesuai dengan maksud dan tujuan bangsa. Selain itu juga budi pekerti menurut Ki Hadjar bukanlah sekedar konsep teoritis sebagaimana yang dipahami masyarakat pada umumnya. Pengajaran budi pekerti juga bukan berarti mengajar teori tentang baik buruk, benar salah dan seterusnya; bukan pula mengajar dalam bentuk pemberian kuliah atau ceramah tentang hidup kejiwaan atau peri keadaban manusia dan atau keharusan memberi keterangan-keterangan tentang budi pekerti secara luas dan mendalam. Pengajaran budi pekerti, tegas Ki Hadjar, diterapkan untuk menyokong perkembangan hidup anak-anak, menuju kea rah peradapan dalam sifatnya dan umumnya, seperti pengajaran anak bagaimana duduk yang baik, tidak berteriak-teriak agar tidak mengganggu oaring lain, bersih badan dan pakaian, hormat terhadap ibu bapak dan orang lain, suka menolong dan lain sebagainya (Abuddin: 2005).

Adapun pendidikan merupakan hal yang sangat penting bagi kehidupan manusia, karena pendidikan juga merupakan sektor yang mendukung dalam meningkatkan dan mengembangkan sumber daya manusia (human resources development) untuk menjawab tantangan masa depan yang berat akibat makin berkembangnya ilmu pengetahuan dan teknologi, 
83 | Pendampingan Belajar Membentuk Karakter Anak Yang Terdampak Pandemi Covid-19 Melalui Kegiatan Interaksi Alam Dan Sosial Di Dusun Krajan Desa Kedunggebang Kecamatan Tegaldlimo Kabupaten Banyuwangi

terutama dalam pemanfaatannya. Hal ini sesuai dengan pendapat (Rahman, 2018), bahwa pendidikan adalah salah satu faktor yang sangat menentukan dan berpengaruh terhadap perubahan sosial

Adapun menurut Barhani dan Arifin (2012: 65) beliau mengemukakan bahwa kualitas pendidikan dan pembelajaran akan menjadi kunci utama dalam peningkatan kemampuan siswa dalam berintraksi dengan lingkungan. Sedangkan pembelajaran yang terencana dan sengaja diciptakan (intentional learneing) Bukan belajar yang terjadi secara insidental (incidental learning) Gagne menyatkan bahwa pembelajaran adalah serangkaian aktivitas yang sengaja diciptakan dengan maksud untuk memudahkan proses belajar sebagai pengembangan penyampaian informasi dan komuniksasi dengan tujuan yang spesifik, agara pembelajaran yang dilapangan disusun secara sistematis dan akurat. Akan tetapi menurut pandangan Rusman (2012: 121) bahwa perlunya sebuah perencanaan yang tepat dalam pemilihan atau penetapan tujuan organisasi atau penentuan strategi, kebijakan, proyek, program, metode, system, anggaran dan standar yang di perlukan dalam pencapai kesepakatan dalam perencanaan untuk memberikan kejelasan setiap kegiatan yang dilaksanakan secara efisien, efektif dan berkelanjutan.

Hal ini mengenai aspek pendidkan karakter menurut Hamid dan saebani (2013) mengatakan bahwa secara akademik, Pendidikan karakter di maknai sebagai pendidikan nilai, Pendidikan budi pekerti, Pendidikan moral, Pendidikan watak yang tujuannya mengembangkan kemampuan siswa untuk memberikan keputusan baik-buruk, memelihara yang baik dan mewujudkan kebaikan dalam kehidupan sehari-hari. Aspek-aspek Pendidikan karakter terdiri dari Sembilan pilar yang saling terkait, yaitu:

a. Tanggung jawab (responsibility) artinya menghadapi resiko dari perbuatan yang sudah dilakukan;

b. Rasa hormat (respect) artinya bersikap sopan, etis, dan menghargai orang lain secara proporsional;

c. Keadilan (fairness) artinya meletakkan segala sesuatau sesuai dengan porsinya, hiup tertib dan disiplin tidak berpihak karena kepentingan yang menguntungkan diri sendiri, dan menaati hukum tanpa pamrih dan penuh kesadaran dan keikhlasan;

d. Keberanian (courage) artinya berani menegakkan kebenaran atas nama kebenaran;

e. Kejujuran (honesty), artinya menjauhkan diri dari sikap penuh dusta; 
f. Kewarganegaraan (citizencip), artinya mengerti dan menjalankan kehidupan sosial kemasyarakatan sebagai warga negara yang baik dan taat hukum'

g. Disiplin diri (self-discipline), artinya menjalani kehidupan dengan teratur dan terencana dan tidak bersikap sembrono, serta berhati-hati;

h. Peduli (caring) artinya berempati kepada nasib orang lain dan memiliki kemampuan ikut meringankan bebennya;

i. Ketekunan (perseverance), artinya memerhatikan dan mengambil pelajaran dari sisi positif dari semua pengalaman hidup, meningkatkan pemahaman kognitif terhadap semua pelajaran yang diperoleh dari bangku sekolah dan masyarakat.

Kegiatan yang dilakukan peneliti ini yakni bertempat di dusun krajan desa kedunggebang guna untuk membentuk karakter anak terdampak pandemi covid-19 agar lebih kreatif, percaya diri, dan rasa cinta terhadap alam. Selain itu, terdapat karakter yang tidak lepas di lingkungan sekitar yaitu karakter peduli sosial dan karakter Islamia tau relegius. Hal ini di karenakan rumah anak yang terdampak pandemi dekat dengan Musholla dan lembaga TPQ.

Setiap halnya perencanaan untuk kegiatan interaksi alam dan sosial dalam membentuk karakter anak yang terdampak pandemi covid-19 yang di selenggarakan pada tanggal 11 juni 2020 dengan mengawali peneliti mendampingi belajar anak terdampak covid-19 dengan tujuan pengenalan terhadap anak (siswa) yang bertempat disalah satu rumah mereka yakni di dusun krajan.

\section{Perencanaana Pendampingan Belajar Membentuk Karakter Anak Yang Terdampak Pandemi Covid-19 Dengan Melalui Kegiatan Interaksi Alam Dan Sosial Di Dusun Krajan}

Dalam pelaksanaan kegiatan program dari hasil pendampingan dan dokumentasi seorang peneliti membentuk karakter anak yang terdampak pandemi dengan kegiatan interaksi alam dan pembelajaran untuk peduli terhadap masyarakat yang membutukhan. Berikut ini adalah perencanaan kegiatan yang dilakukan dalam memanfaatkan lingkungan (alam dan sosial) umtuk membentuk pada anak-anak mereka (anak yang terdampak).

\section{a. Kegiatan Interaksi Alam}

Interaksi yang terjadi antara manusia dengan lingkungan alam 
85 | Pendampingan Belajar Membentuk Karakter Anak Yang Terdampak Pandemi Covid-19 Melalui Kegiatan Interaksi Alam Dan Sosial Di Dusun Krajan Desa Kedunggebang Kecamatan Tegaldlimo Kabupaten Banyuwangi

adalah interaksi yang mengharuskan manusia menyesuaikan diri dengan alam dan menjadikan manusia dapat memanfaatkan alam sekitarnya. Interaksi antara manusia dengan lingkungan alam dapat berlangsung dengan positif maupun negatif. Alam merupakan titipan yang diberikan tuhan untuk manusia sebagai kholifah di muka bumi ini, jadi salah satu pelatihan penyadaran anak untuk peduli terhadap lingkungan alam di era pandemi saat ini dengan kegiatan pendampingan kepedulian taman dan tumbuhan disekitar rumah mereka, yakni dengan mengenalkan pentingnya kita dalam bersosialisasi terhadap alam sekitar dengan merawat, menanam, bahkan menyadarkan kepada mereka kalua tumbuhan juga memiliki hak hidup seperti yang di rasalkan kita. Dengan ini suatu pembelajaran tak lagi abstrak bagi siswa karena mereka dapat langsung menerapkannya dengan media belajar yang ada di alam sekitar tempat tinggal mereka. Karena alam bisa menjadi sumber pengetahuan yang baik bagi anak-anak di rumah di era pandemi saat ini. Hal ini untuk membentuk karakter mereka dengan kegiatan seperti itu, juga mengajarkan kepada orang tua untuk memunculkan inovasi pembelajaran karakter dirumah. Sebenarnya kegiatan tersebut biasa dilaksanakan di sekolahan yakni kegiatan ekstra kurikuler melalui sebuah kegiatan tambahan yang berorientasi pembinaan karakter siswa, seperti kegiatan pramuka yang materinya biasanya di ajarkan di sekolahan.

Selain itu Interaksi dengan alam itu bukan hanya dirasakan dari lingkungan sekolah yang luas dan asri karena ditumbuhi dengan beragam pepohonan dan bangunan kelas yang ramah lingkungan. Akan tetapi kegiatan tersebut bisa kita lakukan di lingkungan sekitar rumah mereka masing-masing, karena adanya penutupan sementara lembaga pendidikan sebagai upaya menahan penyebaran pendemi covid-19 yang berdampak pada jutaan pelajar, tidak kecuali di Indonesia. Sebagaimana mestinya Indonesia merencanakan, mempersiapkan, dan mengatasi pemulihan covid-19, untuk menekan kerugian dunia pendidikan dimasa mendatang. Dengan melihat hal ini perlunya suatu inovasi belajar untuk membentuk karakter anak dengan melalui kegiatan interaksi alam dan sosial. Yang terpenting justru bagaimana orang tua bisa mentransfer ilmu pengetahuan, membentuk karakter, mengajarkan berbagai keterampilan hidup, dan kewirausahaan lewat kegiatan-kegiatan bernuansa alam atau kegiatan-kegiatan yang dilaksanakan sehari-hari dirumah masing-masing, baik itu dengan melatih anak merawat tanaman, mengajarkan anak 
pentingnya terhadap tempat tinggal hewan ataupun bagaimana cara untuk kita peduli terhadap mahluk ciptaan tuhan karena kita sebagai kholifah di muka bumi ini, yaitu diberi wewenang oleh Allah agar melaksanakan perintahnya di muka bumi untuk mengelola bumi dan seisinya, serta kemampuan untuk menghindari pertumpahan darah dan kerusakan. Hal ini merupakan suatu kegiatan pembelajaran karakter yang di tanamkan pada diri seorang anak, melalui inovasi pengajaran yang arahkan oleh orang tua.

Wulansari (2016: 8), menyatakan bahwa Model Pembejaran Berbasis Alam (PBA) adalah model pembelajaran yang berprinsip pada belajar tentang alam, belajar menggunakan alam, dan belajar bersama alam. Belajar tentang alam artinya Model pembelajaran berbasis alam mempelajari konsep-konsep alam sebagai materi pembelajarannya.

Wulandari (2017: 2), model pembelajaran berbasis alam ini memiliki manfaat dan tujuan untuk meningkatkan kualitas proses belajar dalam pendidikan sekolah dasar dan secara spesifik tujuan model pembelajaran berbasis alam adalah sebagai berikut :

1) Menyediakan pembelajaran secara nyata bagi anak.

2) Menyediakan lingkungan belajar bagi anak.

3) Menyediakan anak waktu yang memadai dan berkesinambungan.

4) Memfasilitasi proses belajar anak melalui interaksi dengan orang dewasa dan teman sebaya.

5) Memfasilitasi pembelajaran individual untuk anak.

6) Menyediakan kesempatan anak mengembangkan aspek perkembangan nilai agama dan oral, fisik motorik, kognitif, bahasa, sosial emosional dan seni.

7) Membantu Educational For Sustainable Development Programs untuk mengembangankan pendidikan berkelanjutan di bidang kelestarian alam.

Dilihat dari penjelasan model pembelajaran atau pelaksanaan kegiatan, di situ nampak jelas bahwa kegiatan ini di rancang untuk membentuk kepribadian atau karakter yang baik yang di harapkan oleh orang dalam pola merubah menset pemikirannya untuk selalu melindungi alam dan menjadikan hari-hari liburnya untuk hal yang bermanfaat. 
87 | Pendampingan Belajar Membentuk Karakter Anak Yang Terdampak Pandemi Covid-19 Melalui Kegiatan Interaksi Alam Dan Sosial Di Dusun Krajan Desa Kedunggebang Kecamatan Tegaldlimo Kabupaten Banyuwangi

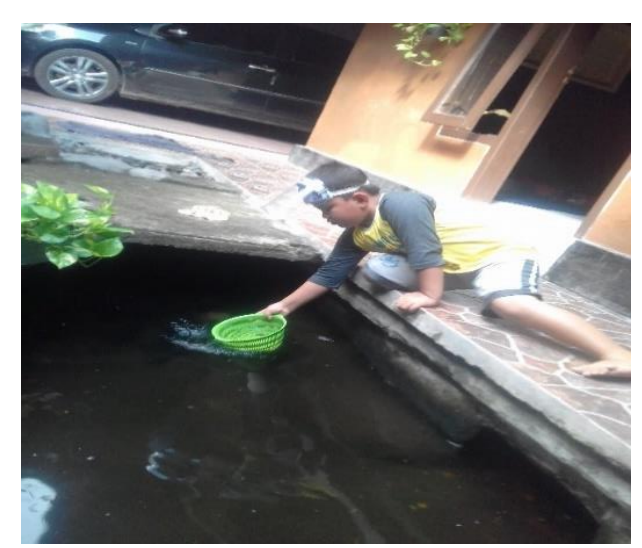

Gambar 1. Hasil kegiatan yang sudah diterapkan

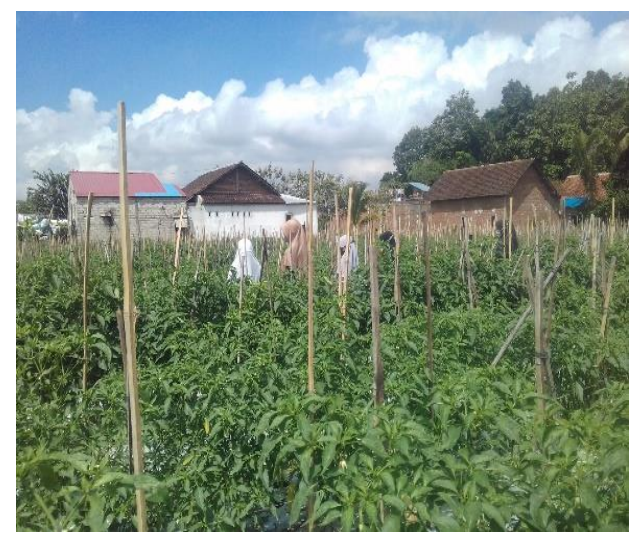

Gambar 2. Pengenalan lingkungan persawahan

\section{b. Kegiatan Interaksi sosial}

Manusia adalah makhluk sosial tentu tidak mungkin bisa memisahkan hidupnya dengan manusia lain. Bukan hal rahasia lagi bahwa segala bentuk budaya, tatanan hidup dan sistem kemasyarakatan terbentuk karena interaksi dan benturan kepentingan antara satu manusia dengan manusia lainnya. Adapun keutuhan manusia akan tercapai jika manusia mau menyelaraskan perannya sebagai makhluk ekonomi dan sosial.

Adapun Interaksi sosial menurut (Soekanto, 1992: 67) merupakan hubungan sosial yang menyangkut hubungan antar individu, individu dengan kelompok, dan kelompok dengan kelompok. Interaksi sosial akan terjadi jika adanya sebuah kontak sosial dan adanya komunikasi. Sedangkan Interaksi sosial merupakan kunci dari semua kehidupan sosial, oleh karena itu tanpa interaksi sosial, tak akan mungkin ada kehidupan bersama. Pada anak usia dini interaksi sosial memanglah sangat dibutuhkan karena anak nantinya akan diajarkan bagaimana hidup bermasyarakat, lalu anak juga akan diajarkan berbagai peran yang nantinya akan menjadi indentifikasi dirinya, selain itu pula saat melakukan interasi sosial anak akan memperoleh berbagai informasi yang ada disekitarnya.

Adapun pengertian interaksi sosial menurut para ahli dapat dikemukakan sebagai berikut:

1) Interaksi sosial (Elly\&Kolip:2011) adalah hubungan-hubungan sosial yang dinamis yang berkaitan dengan orang perorangan, kelompok perkelompok, maupun perorangan terhadap perkelompok ataupun sebaliknya. 
2) Interaksi sosial (Soekarto: 2010) adalah hubungan timbal balik antara individu dengan individu, individu dengan kelompok, dan kelompok dengan kelompok.

Tujuan yang lain dari pendidikan karakter adalah untuk membentuk bangsa yang tangguh, kompetitif, berakhlak mulia, bermoral, bertoleran, bergotong-royong, berjiwa patriotik, berkembang dinamis, berorientasi ilmu pengetahuan dan teknologi yang semuanya dijiwai oleh iman dan takwa kepada

Tuhan Yang Maha Esa Sri Narwanti, (2011: 16). Sikap gotong royong inilah yang akan dibangun di dalam diri peserta didik di sekolah yang diharapkan dapat menghapuskan pergaulan yang selalu pilih- pilih. Selain itu juga peneliti bertujuan untuk membuka mindset mereka untuk tidak memanjamanjakan dirinya dengan mehambur-hamburkan uangnya untuk hal yang tidak bermanfaat dan mengajak mereka untuk terjun langsuk dalam sosialisasi terhadap perjuangan orang tua dalam membesarkan putranya sampai beliau jatuh sakit.

Adapun hasil yang di capai dalam kegiatan interaksi sosial ini, bahwa anak mulai berfikir dan berinovasi dalam membuka usaha untuk membantu dalam meringankan perekonomian keluarga.

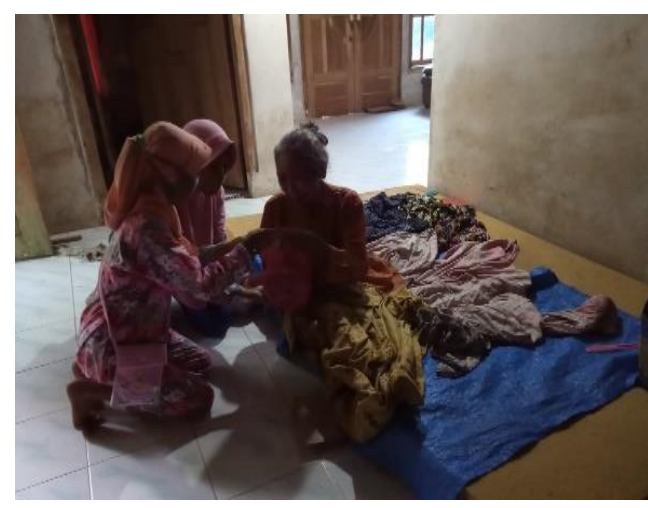

Gambar 3. Kegiatan sosialisasi masyarakat

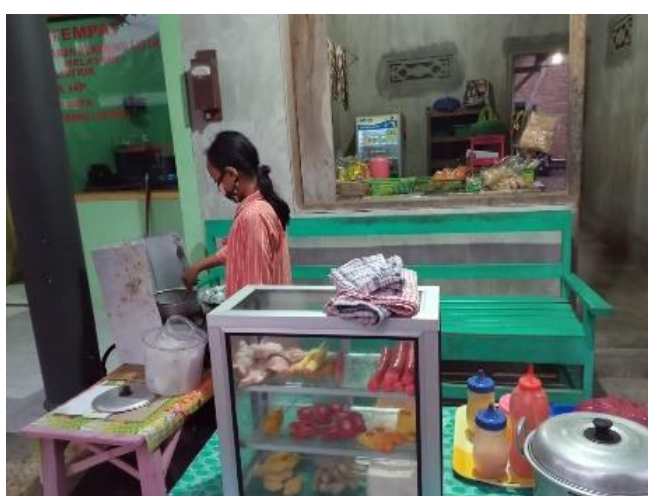

Gambar 4. Inovasi kegiatan anak setelah pendampingan

\section{c. Pembentukan Karakter Religius}

Karakter religius adalah suatu penghayatan ajaran agama yang dianutnya dan telah melekat pada diri seseorang dan memunculkan suatu sikap atau perilaku dalam kehidupan sehari-hari baik dalam bersikap maupun dalam bertindak yang dapat membedakan dengan karakter orang lain. Adapun Pendidikan karakter dan Pendidikan agama adalah dua hal yang saling 
89 | Pendampingan Belajar Membentuk Karakter Anak Yang Terdampak Pandemi Covid-19 Melalui Kegiatan Interaksi Alam Dan Sosial Di Dusun Krajan Desa Kedunggebang Kecamatan Tegaldlimo Kabupaten Banyuwangi

berhubungan. Sehingga dalam hal ini pendampingan juga di lakukan dengan kegiatan-kegiatan yang menyangkut dengan keagamaan mereka, baik dalam segi praktek sholatnya, bagimana cara mengaji yang baik dan pengarahan mengenai apa tujuan hidup di dunia.

\section{SIMPULAN}

Berdasarkan kegiatan pendampingan yang telah dilakukan, dapat di Tarik kesimpulan sebagai berikut:

Adapun kebingungan orang tua dalam membentuk dan mendampingi pembelajaran karakter pada putra-putrinya di era pandemi saat ini, karena kurangnya inovasi pembelajaran yang dimiliki. Sehingga peneliti mengarahkan melalui kegiatan interaksi alam dan sosial di area sekitar akan membangkitkan semangat belajar siswa dan mengarahkan kebiasaan siswa dalam membentuk karakter yang baik, serta membantu orang tua dalam hal metode pengajaran inovasi untuk membentuk karakter anak-anaknya dan pembelajaran relige terutama disaat libur sekolah diera pandemi covid-19 ini dengan ketentuan harus tetap mengikuti protokol kesehatan.

Dalam membentuk karakter anak untuk peduli terhadap orang lain dan lingkungan sekitar di era pandemi saat ini, dengan pengarahan interaksi sosial langsung dengan mengukuti protokol Kesehatan. Interaksi sosial akan terjadi jika adanya sebuah kontak sosial dan adanya komunikasi. Untuk itu dengan melakukan interasi sosial anak akan memperoleh berbagai informasi yang ada disekitarnya, dengan tujuan untuk membuka mindset mereka sehingga karakter untuk membentuk pribadi yang tangguh, kompetitif, berakhlak mulia, bermoral, bertoleran, bergotong-royong, berjiwa patriotik, berkembang dinamis, berorientasi ilmu pengetahuan dan teknologi yang semuanya dijiwai oleh iman dan takwa kepada Tuhan Yang Maha Esa.

\section{DAFTAR RUJUKAN}

Abdullah, Ridwan Sani, (2015). Inovasi Pembelajaran. Jakarta: Bumi Aksara.

As' adi, M., \& Muttaqin, A. I. (2019). PENDAMPINGAN KEGIATAN

KEAGAMAAN DI MASJID AL FALAH DUSUN KRAJAN DESA

SILIRAGUNG KECAMATAN SILIRAGUNG BANYUWANGI. ABDI

KAMI: Jurnal Pengabdian Kepada Masyarakat, 1(2), 105-114. 
Buana, Dana Riksa, (2020). "Analisis Perilaku Masyarakat Indonesia dalam Menghadapi Pandemi Virus Corona (Covid-19) dan Kiat Menjaga Kesejahteraan Jiwa," Salam: Jurnal Sosial dan Budaya Syar-i, Volume 7, No. 3.

Barnawi \& M. Arifin, (2012). Strategi \& Kebijakan Pembelajaran Pemdidikan Karakter, (Jogjakarta: Ar Ruzz Media).

Departemen Pendidikan Nasional, (2003). Undang-Undang Republik Indonesia No. 20 Tahun 2003 tentang Sistem Pendidikan Nasional. Jakarta: Depdiknas.

Inter-Agency Standing Committee (IASC), (2007). IASC Guidelines on Mental Health and Psychosocial Support in Emergency Settings. IASC: Geneva..

Narwanti, Sri. (2011). Pendidikan Karakter.Yogyakarta: Familia.

Nata, Abuddin, (2005). Tokoh-tokoh Pembaruan Pendidikan Islam di Indonesia. Jakarta: Rajagrafindo Persada.

Masnur, Muslich, (2011). Pendidikan Karakter Menjawab Tantangan Krisis Multidimensional. Jakarta: Sinar Grafika Offset.

Kolip, Elly M Setiadi \& Usman, (2011). Pengantar Sosiologi. Pemahaman Fakta dan Gejala Permasalahan Sosial: Teori, Aplikasi, dan Pemecahannya. Jakarta.

ONG Inclusiva, (2000). Recommendations for health protection of people with disabilities during outbreaks: Lessons learned from the 2019 Novel Coronavirus. ONG Inclusiva.

Rahman, K. (2018). Perkembangan Lembaga Pendidikan Islam di Indonesia. Tarbiyatuna: Kajian Pendidikan Islam, 2(1), 1-14.

Roger, Kauchak, (2012). The Condition of Learning. Singapore: Allyn and Bacon. Robbins, Stephens, (2010). Instructional Design Theories and Models. NJ: Lawrence Erlbaum. 
91 | Pendampingan Belajar Membentuk Karakter Anak Yang Terdampak Pandemi Covid-19 Melalui Kegiatan Interaksi Alam Dan Sosial Di Dusun Krajan Desa Kedunggebang Kecamatan Tegaldlimo Kabupaten Banyuwangi

Schumpeter, T.L, (2010). Teacher Expectation and Student Perception. New York: Holt Rinehart and Winston

Soekanto, Soerjono, (2010). Sosiologi Suatu Pengantar. Jakarta: Rajawali Press.

World Health Organization (WHO), 2005. Mental Health and Psychosocial Consideration in Pandemic Human Influenza (2005 Draft version).

Wulansari, Betty Yulia \& Sugito, (2016). Pengembangan Model Pembelajaran Berbasis Alam Untuk Meningkatkan Kualitas Proses Belajar anak Usia Dini. Jurnal Pendidikan dan Pemberdayaan Masyarakat Volume 3 Nomor 1, (16 - 27). Yogyakarta: Universitas Negeri Yogyakarta.

Wulansari, Betty Yulia, (2017). Model Pembelajaran Berbasis Alam Sebagai Alternatef Pengembangan Karakter Peduli Lingkungan. Jurnal dimensi pendidikan dan pembelajaran Vol. 5 No. 2 Jul. Ponorogo: Universitas Muhammadiyah Ponorogo. 